\title{
Groundwater Management by Using Hydro-Geophysical Investigation: Case Study: An Area Located at North Abu Zabal City
}

\author{
Sultan Awad Sultan Araffa \\ National Research Institute of Astronomy and Geophysics, Helwan, Cairo
}

Egypt

\section{Introduction}

Geophysical methods are applied to investigate geological structures, to identify promising areas, and to locate ore bodies by clarifying the distributions of physical properties in the Earth. Geophysics is a major discipline of the Earth sciences and a subdiscipline of physics, is the study of the whole Earth by the quantitative observation of its physical properties. Geophysical survey data are used to analyze potential petroleum reservoirs and mineral deposits, to locate groundwater, to locate archaeological finds, to find the thicknesses of glaciers and soils, and for environmental remediation. The theories and techniques of geophysics are employed extensively in the planetary sciences in general. Geophysical methods provide information about the physical properties of the earth's subsurface. There are two general types of methods: Active, which measure the subsurface response to electromagnetic, electrical, and seismic energy; and passive, which measure the earth's ambient magnetic, electrical, and gravitational fields. Geophysical methods can also be subdivided into either surface or borehole methods. Surface geophysical methods are generally non-intrusive and can be employed quickly to collect subsurface data. Borehole geophysical methods require that wells or borings be drilled in order for geophysical tools to be lowered through them into the subsurface. This process allows for the measurement of in situ conditions of the subsurface.

All geophysical techniques are based on the detection of contrasts in different physical properties of materials. If contrasts do not exist, geophysical methods will not work. Reflection and refraction seismic methods contrast compressional or shear wave velocities of different materials. Electrical methods depend on the contrasts in electrical resistivities. Contrasts in the densities of different materials permit gravity surveys to be used in certain types of investigations. Contrasts in magnetic susceptibilities of materials permit magnetic surveying to be used in some investigations. Contrasts in the magnitude of the naturally existing electric current within the earth can be detected by self-potential (SP) surveys. Seismic refraction surveys are used to map the depth to bedrock and to provide information on the compressional and shear wave velocities of the various units overlying bedrock. Velocity information also can be used to calculate in place small-strain dynamic properties of these units. Electrical resistivity surveys are used to provide information on the depth to 
bedrock and information on the electrical properties of bedrock and the overlying units. Resistivity surveys have proven very useful in delineating areas of contamination within soils and rock and also in aquifer delineation. Gravity and magnetic surveys are not used to the extent of seismic and resistivity surveys in geotechnical investigations, but these surveys have been used to locate buried utilities. Self-potential surveys have been used to map leakage from dams and reservoirs. Geophysical surveys provide indirect information. The objective of these surveys is to determine characteristics of subsurface materials without seeing them directly. Each type of geophysical survey has capabilities and limitations and these must be understood and considered when designing a geophysical investigations program. The analysis and processing of the geophysical data includes the mapping of surface features, the application of mathematical filters, the drawing of the geophysical grids, image processing techniques, modeling and mapping of the geophysical anomalies, etc..

Regional variations in density, resistivity, susceptibility, radioelement composition or reflectance spectra measured by geophysics can all be used to map geology or geomorphology. Large areas can be flown at a relatively low cost compared to ground surveys. The multiple sets of geophysical data can be combined with known geology to create regional geology maps and to develop priorities for follow-up on the most highly prospective ground. Interpreted geological structures such as shear zones, unconformities, or contacts may be strong indicators of economic mineralization. Mapping geology with geophysics has the power to extend geological knowledge into areas where the geology is covered, by transported sediment, for example. If the geophysical interpretation is constrained by regional geology, or spot observations of local geology, an effective geological map can be created for the entire survey area. Combining geophysical methods enhances the accuracy of the map(s) generated which they are more than the sum of the parts. Many rocks may be similar in one geophysical parameter, but vastly different in another.

Numerous geologic structures that can focus ground water flow can be identified by various geophysical surveys. Aquitards can be identified by direct current or electromagnetic resistivity studies. Clay lenses are less resistive than sand and gravel bearing aquifers, unless contained pore water is ion rich or highly acidic, in which case the aquifers may be less resistive. Reflection seismic and ground penetrating radar may distinguish subtle velocity and resistivity changes related to distributions of aquifers and aquitards in sedimentary environments. Pore fluid with properties that vary laterally and with depth cause some uncertainties in aquitard delineation. Lithologic boundaries and faults may be associated with porosity contrasts that may concentrate ground water flow. Porosity contrasts are associated with density, resistivity, and acoustic velocity contrasts, and some may have associated gamma-ray contrasts. In most cases, increased porosity lowers density and resistivity, the latter resulting from an increase of conductive pore fluid. In crystalline bedrock, faults and lithologic boundaries commonly have density and magnetic contrasts related to rock composition but ambiguities may result from subtle mineralogical changes in associated rocks. Bedrock topography, including structural highs and buried channels, that influence ground water flow may contrast with overlying sedimentary and alluvial cover in having higher density, magnetization, and resistivity. These contrasts may be identified using gravity, resistivity, ground-penetrating radar, and seismic refraction and reflection. Anomalies may be small and ambiguities in defining bedrock topography or buried channels include equivalent amplitude anomalies from variable properties of both bedrock and overburden 
Resistivity is a geophysical method that images the earth by measuring the potential generated by injecting DC electricity into ground. The resulting geoelectrical image show the distribution of the earth' resistivity, which can be related to different soil and rock type. Many authors discussed the theory and application of resistivity method such as Keller and Frischknecht (1996), Teloford et al (1990) and Ward (1990). Electrical resistivity imaging (ERI) has become an important engineering and environmental site investigation tool, Laurence and Mehran (2004). Resistivity images are created by inverting hundreds to thousands of individual resistivity measurements (e.g., Loke and Barker, 1996a,b) to produce an approximate model of the subsurface resistivity. Rijo (1984) illustrated a simple inversion algorithm that uses a data bank of forward solutions for a certain class of 3D models. Li and Oldenburg (1992) proposed an inversion method based on the Born approximation Sultan and Santos (2008), Santos and Sultan (2008) used 1-D and 3D resistivity inversion for groundwater exploration and engineering geology.

\subsection{Electrical resistivity}

The electrical resistivity of any material depends largely on its porosity and the salinity of the water in the pore spaces. Although the electrical resistivity of a material may not be diagnostic, certain materials have specific ranges of electrical resistivity. In all electrical resistivity surveying techniques, a known electrical current is passed through the ground between two (or more) electrodes. The potential (voltage) of the electrical field resulting from the application of the current is measured between two (or more) additional electrodes at various locations. Since the current is known, and the potential can be measured, an apparent resistivity can be calculated. The separation between the current electrodes depends on the type of surveying being performed and the required investigation depth. Electrical resistivity, also referred to as galvanic electrical methods, is occasionally useful for determining shallow and deep geologic and hydrogeologic conditions. By measuring the electrical resistance to a direct current applied at the surface, this geophysical method can be used to locate fracture zones, faults and other preferred groundwater/contaminant pathways; locate clay lenses, sand channels and locate perched water zones and depth to groundwater. A variety of electrode configurations or arrays e.g., Wenner, Schlumberger, dipole-dipole can be used depending on the application and the resolution desired. Typically, an electrical current is applied to the ground through a pair of electrodes. A second pair of electrodes is then used to measure the resulting voltage. The greater the distance between electrodes, the deeper the investigation. Because various subsurface materials have different, and generally understood, resistivity values, measurements at the surface can be used to determine the vertical and lateral variation of underlying materials.

Reducing electrical resistivity data is a simple process in which the apparent electrical resistivity is calculated by dividing the measured voltages by the applied current. The quotient is then multiplied by the geometric factor specific to the array used to collect the data. Once the apparent electrical resistivities have been calculated, the next step is to model the data in order geologic structure. The method used to model the apparent electrical resistivity data is specific to each data acquisition mode.

\subsubsection{Sounding mode}

The two most common arrays for electrical resistivity surveying in the sounding mode are the Schlumberger and Wenner arrays. Electrode geometry for both arrays is shown in Figure 1. 


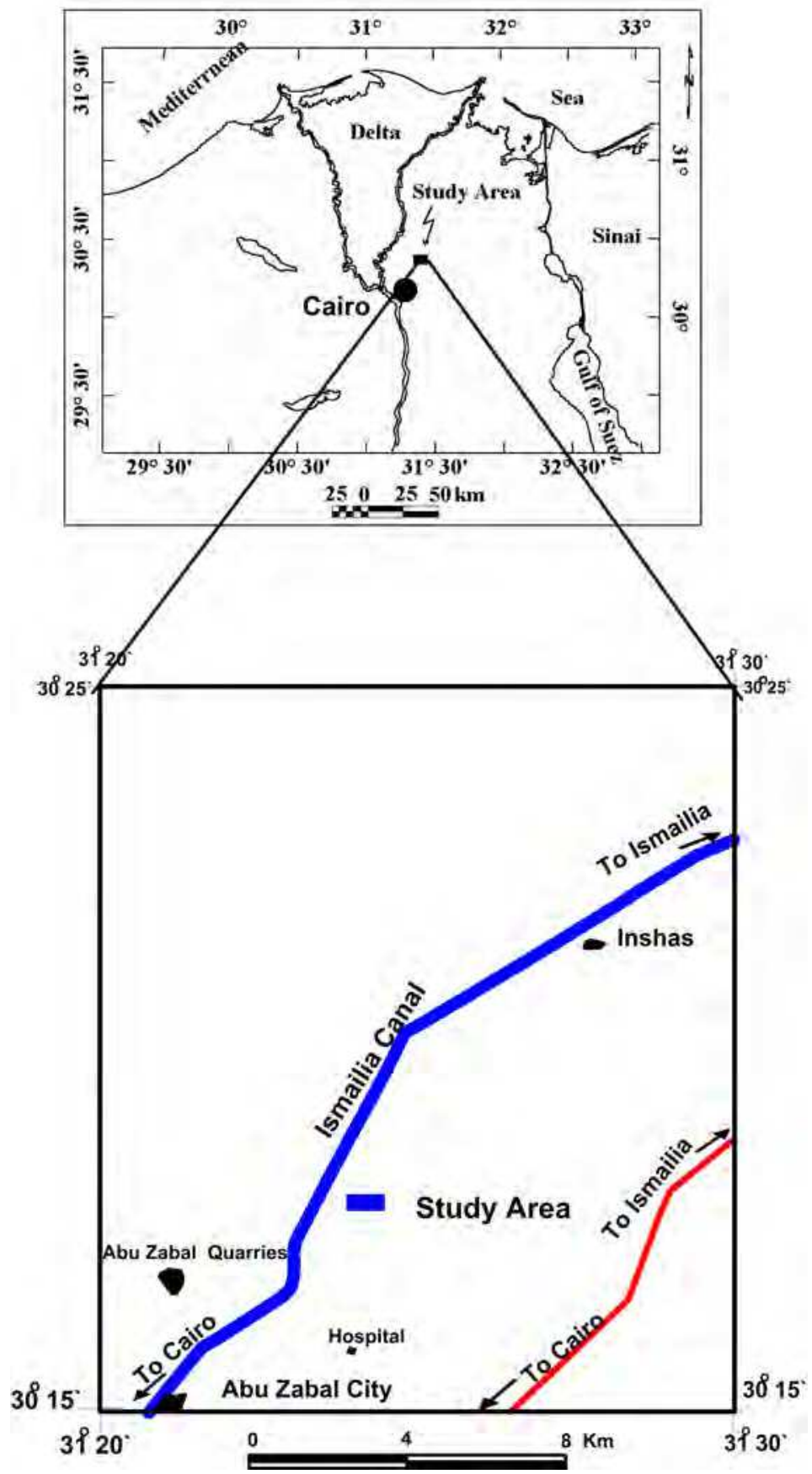

Fig. 1. Location map of the area. 
Increasing the separation of the outer current electrodes, thereby driving the currents deeper into the subsurface increases the depth of exploration. Electrical resistivity sounding surveys measure vertical changes in the electrical properties of subsurface materials. The electrode spacing used for resistivity sounding is variable, with the center point of the electrode array remaining constant. Electrical resistivity data acquired in the sounding mode, using either the Wenner or Schlumberger array, can be modeled using master curves or computer modeling algorithms. When using master curves, the interpreter attempts to match overlapping segments of the apparent electrical resistivity versus electrode separation plots with a succession of two-layer master curves. This modeling method provides coarse estimates of the model parameters, is time consuming, and requires skill on the part of the interpreter. An alternative method of modeling sounding mode electrical resistivity data is to use readily available computer modeling software packages (Sandberg, 1990). There are a variety of different types of algorithms; some assume discrete electrical resistivity layers while others assume that electrical resistivity is a smooth function of depth. The discrete layer algorithms require interaction on the part of the interpreter, but allow for constraining model parameters to adequately reflect known geologic conditions. The continuous electrical resistivity algorithms are automatic, that is, they require no interaction on the part of the operator, and therefore geologic constraints cannot be incorporated into the models.

\subsubsection{Profiling mode}

The two most common arrays for induced polarization/electrical resistivity data collection in the profiling mode are the Wenner and dipole-dipole arrays. The electrode geometry for the Wenner array is the same as the sounding mode where the difference is that in profiling mode the entire array is moved laterally along the profile while maintaining the potential and current electrode separation distances. In the profiling mode, the distance between the potential and current dipoles (a dipole consists of a pair of matching electrodes) is maintained while the array is moved along the profile. Electrical resistivity profiling is used to detect lateral changes in the electrical properties of subsurface material, usually to a specified depth. Electrode spacing is held constant. Electrical resistivity profiling has been used to map sand and gravel deposits, map contamination plumes in hazardous waste studies, and used in fault studies.

In the dipole-dipole array (Fig.2), the typical field procedure is to transmit on a current dipole while measuring the voltages on up to seven of the adjacent potential dipoles. When the data collection is completed for the particular transmitter dipole, the entire array is moved by a distance equal to one dipole separation and the process is repeated. The most frequent source of inaccuracy in electrical resistivity surveying is the result of errors in the placement of electrodes when moving electrodes and/or expanding the electrode array. These distance measurement errors are easily detected on apparent electrical resistivity versus electrode separation curves and for this reason the apparent electrical resistivities should be plotted as the data is acquired in the field. A qualified field geophysicist will recognize these errors and direct the field crew to check the location of the electrodes. The second most common source of error in electrical resistivity surveying is caused by the electrical noise generated by power lines. The most effective means of reducing power line noise is to minimize the contact electrical resistance at the potential electrodes. This can be easily accomplished by using non-polarizing potential electrodes along with wetting the soil under the electrode with water. Non-polarizing electrodes are recommended instead of 
metal potential electrodes, because the metal electrodes generate electrical noise due to oxidation reactions occurring at the metal-soil (pore water) interface.

In the present study 2D dipole-dipole, 3D inversion for 1-D VES and ground magnetic survey were carried at the area located at the north of Abu Zabal city and at distance of $2 \mathrm{~km}$ west Ismailia Canal (branch of River Nile) and cover an area of $0.5 \mathrm{~km}^{2}$ to investigate stratigraghy, structures and groundwater occurrences (Fig.1).

\section{Geology of the area}

The surface geology was described by Geological Survey of Egypt (1998) as shown in Figure 2a where most the study area covered by Quaternary deposits which consist of alluvium, sand sheet and Nile silt and Nile mud. The Miocene deposits occupied the northeastern and southern parts of the area which represented by Hommath formation and composed of sandy limestone, sand, sandstone and clay (Fig.2a). Stratigraphically, the drilled boreholes reflect the rock types with depth in the area. The Quaternary deposits are represented Nile silt and mud, loose sands, sandstone, gravel with a thickness ranging from few meters to 20 $\mathrm{m}$. The Miocene deposits are expressed limestone, sand, sandstone, clay and calcareous sandstone. The Oligocene deposits are represented by basaltic flow and sand and sandstone of Gabal Ahmar Formation. The depth of the upper surface of the basaltic flow ranging from $75 \mathrm{~m}$ at borehole no.7 to $128 \mathrm{~m}$ at borehole no.9. Gabal Ahmar Formation appeared at the borehole no.13 at depth of $113.5 \mathrm{~m}$ to the end of the borehole at depth of $202 \mathrm{~m}$ (Fig.2b).

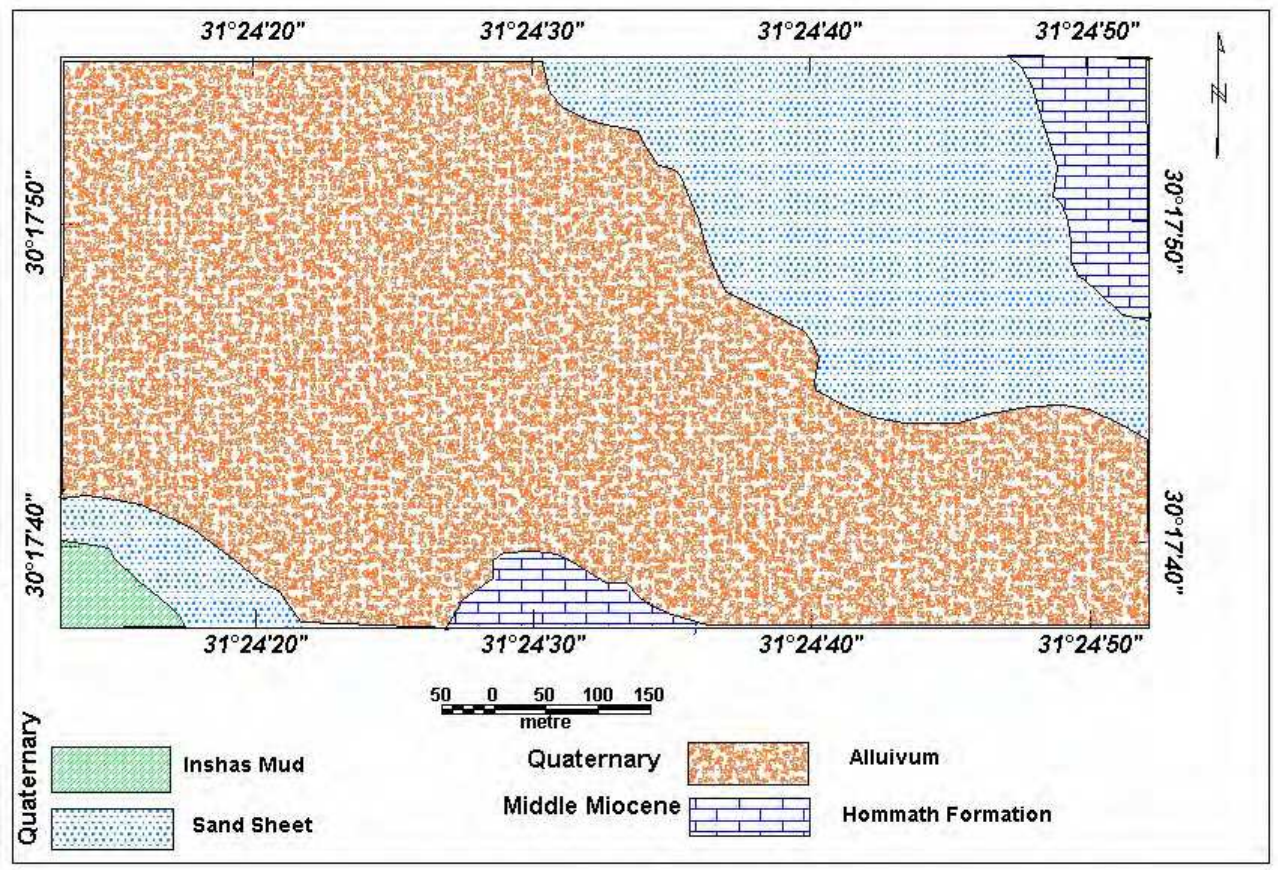

Fig. 2. a. Geological map of the study area 
Groundwater Management by Using Hydro-Geophysical

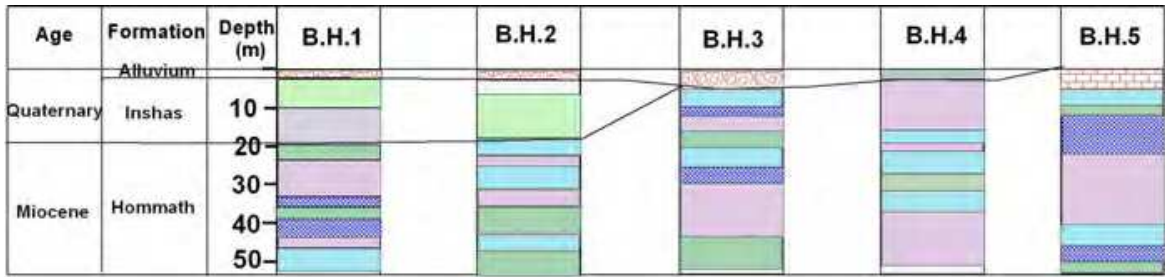

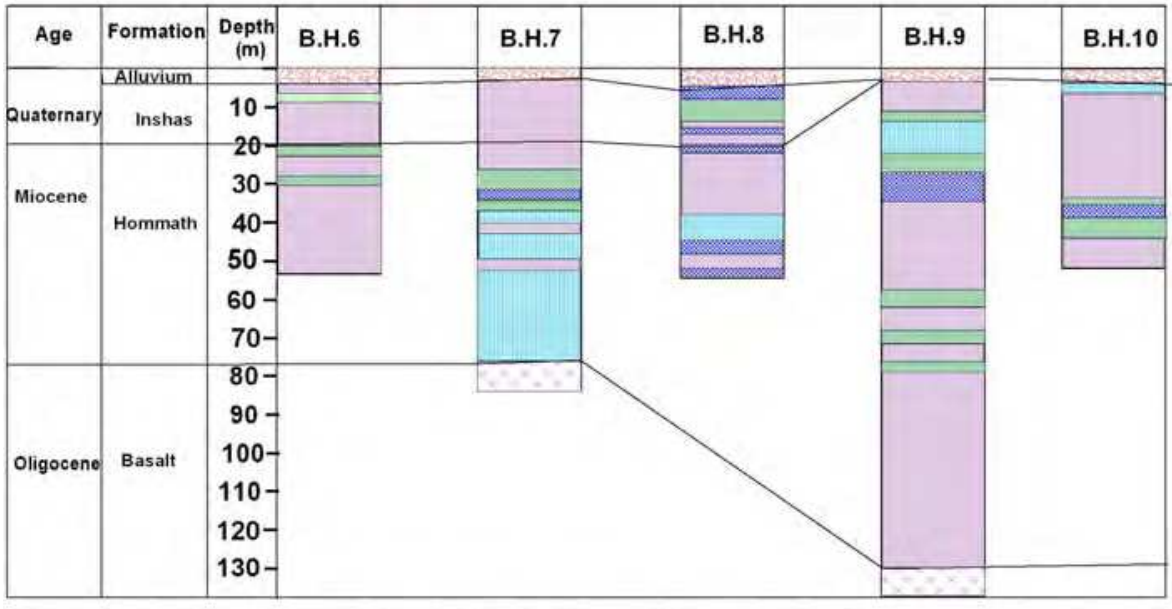

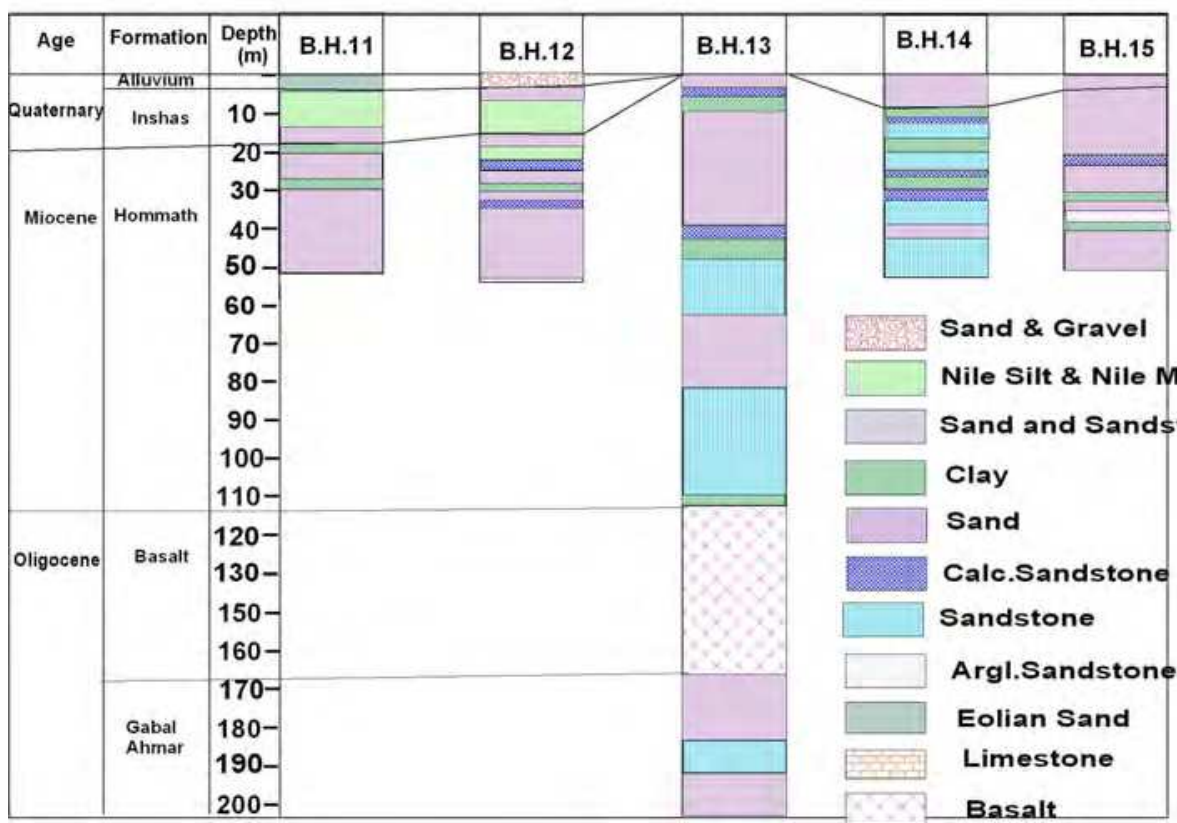

Fig. 2. b. Boreholes description. 


\section{Methodology}

\subsection{Shallow geoelectrical investigation tools}

The shallow investigation tools in the present study were represented by measuring five dipole dipole sections. The length of each section is one kilometer and spacing between sections is $125 \mathrm{~m}$ (Fig.3). The spacing between current electrodes and potential electrodes is a multiple of the electrode spacing $(a)$, in the present study $(a)$ is equal $5 \mathrm{~m}$. The depth of penetration is a function of the distance $a$ (Edwards, 1977; Loke and Barker, 1996b). The dipole-dipole profiles were inverted using the RESINV2D software which produced an image of the electrical resistivity distribution in the subsurface based on a regularization algorithm (Loke and Barker, 1996b). The inverted dipole-dipole section along profile P1-P1 (Fig.4a) exhibits large variation in resistivities where the first half of the section divided into two parts, the first part is shallow depth ranging from 1.1 to $4 \mathrm{~m}$ and shows moderate resistivities ranging from 10 to $50 \mathrm{ohm}$.m corresponding to alluvium deposits, the second part is at depth ranging from 4 to $11.1 \mathrm{~m}$ and exhibits very low resistivities ranging from 1 to $10 \mathrm{ohm} . \mathrm{m}$ corresponding to Nile silt and Nile mud. The second half of the section reflects very high resistivities up to 750 omh.m corresponding to sand sheet and sandstone, the end part of the section reveals moderate and low resistivities corresponding to limestone and clay respectively. The second dipole-dipole section along profile P2-P2 (Fig.4b) reveals low resistivities at the first half of the section according to alluvium and Nile silt and Nile mud, the second half reveals high resistivities corresponding to sand and sandstone with some clay of low resistivities. The dipole-dipole section along profile P3-P3 (Fig.4c) indicates low resistivities for most section corresponding to alluvium and Nile silt and Nile mud, the last part of the section reveals high resistivities at depth ranging from 4 to $11.1 \mathrm{~m}$ corresponding

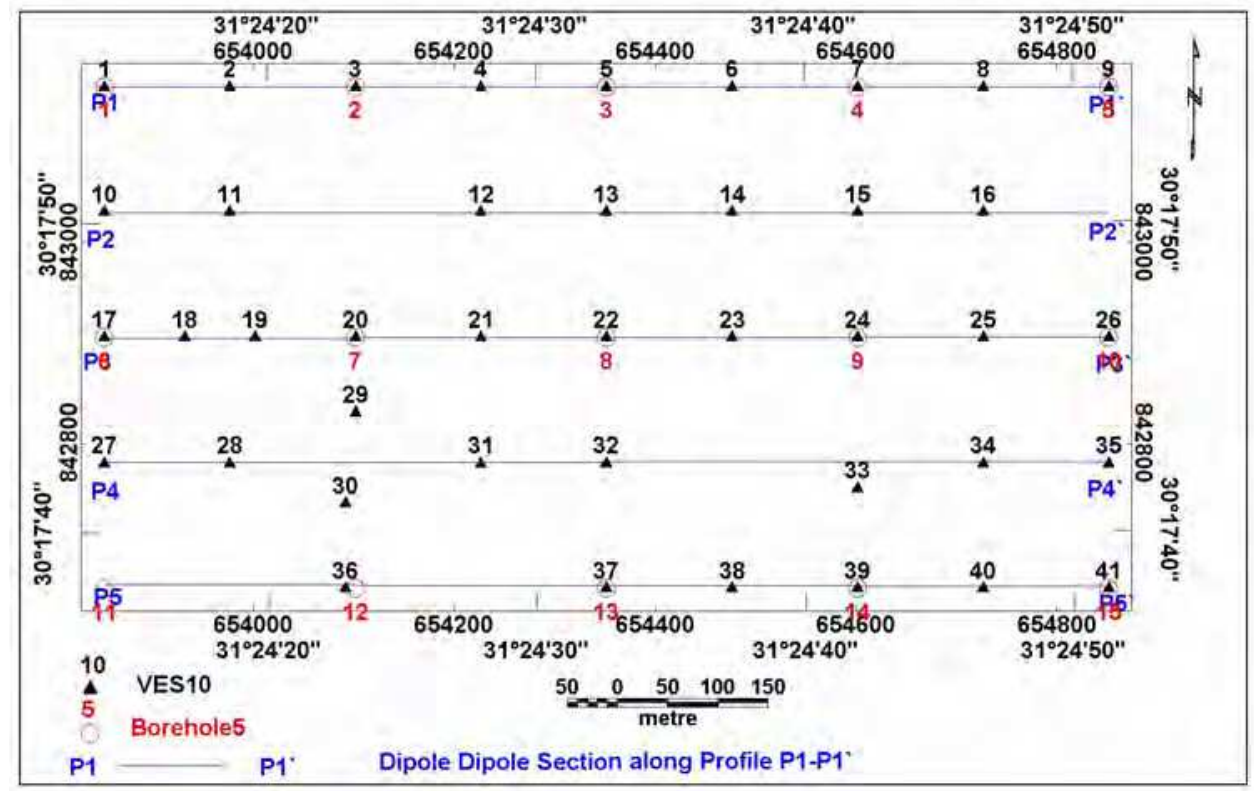

Fig. 3. Location map of geophysical measurements and boreholes 
Groundwater Management by Using Hydro-Geophysical

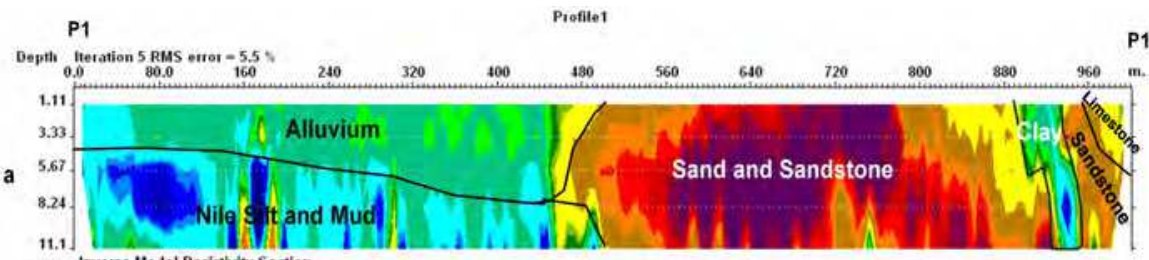

11.1. Imverse Model Restistivity Section

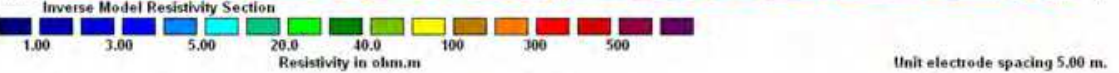

\section{P2}

Profile2

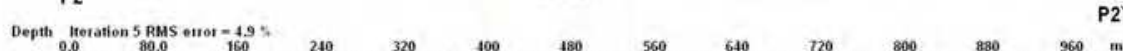

b

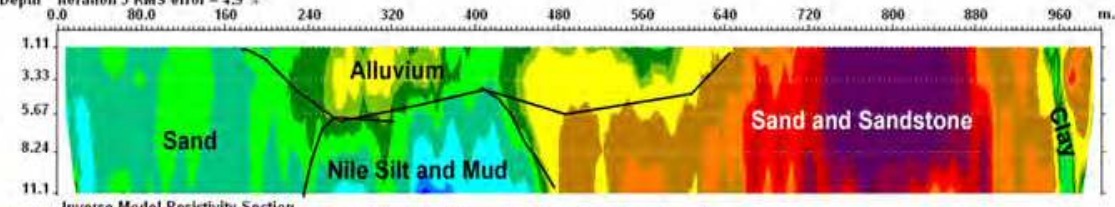

Inverse Model Resistivity Section

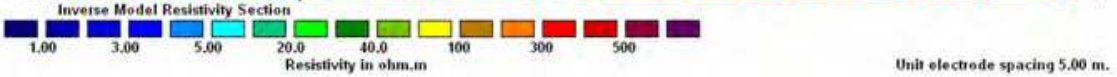

P3

Profile 3

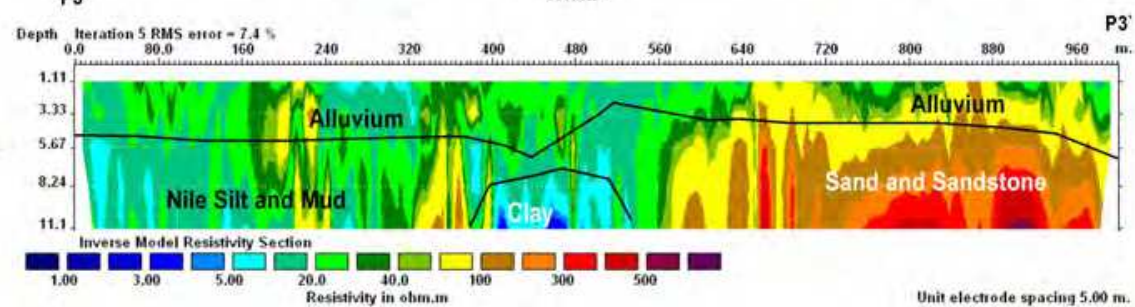

P4

Prefiles

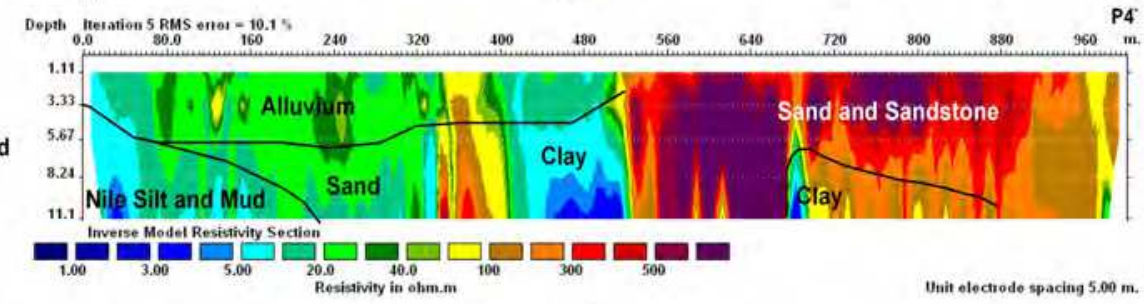

P5 Profiles

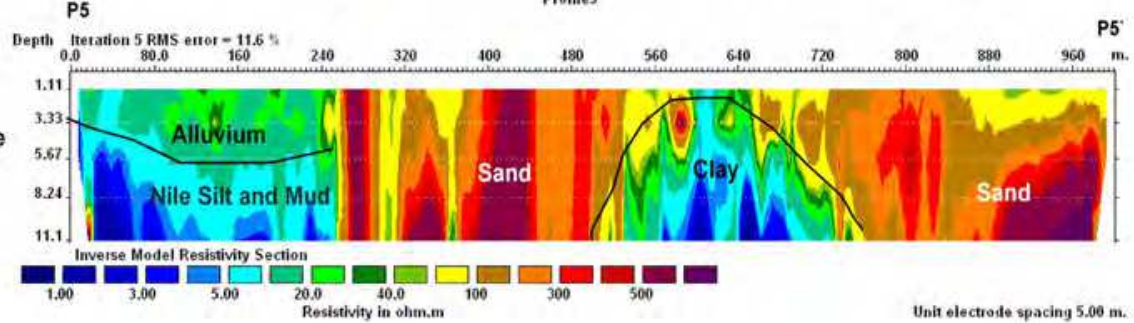

Fig. 4. Dipole-dipole section inverted using RES2DINV program; a. for profile P1-P1', b. for profile P2-P2， c. for profile P3-P3， D. for profile P4-P4 and e. for profile P5-P5'. 
to sand and sandstone. The dipole-dipole section along profile P4-P4 (Fig.4d) shows variation in resistivities ranging from low values according to clay, Nile silt and Nile mud to very high rsistivities of sandstone and sand. The last section along profile P5-P5 (Fig.4e) exhibits at the first and mid part from distance 500 to $720 \mathrm{~m}$ a very low resistivities ranging from 1-10 ohm.m according to clay, Nile silt and Nile mud, the mid part at distance from 250 to $500 \mathrm{~m}$ and the last part of the section reveals very high resistivities corresponding to sand and sandstone.

\subsubsection{3-D representation for dipole-dipole data}

The dipole-dipole data were represented by 3D slices at different depths of 1.1, 3.3, 5.7, 8.2 and $11.1 \mathrm{~m}$ (Fig.5). The slices at depth 1.1 and $3.3 \mathrm{~m}$ reveal low resistivities ranging from 5 to $100 \mathrm{ohm} . \mathrm{m}$ at the most of the area corresponding to alluvium deposits, the northeastern and southeastern parts are occupying by very high resistivity up to $750 \mathrm{ohm}$.m. The slice at depth of $5.7 \mathrm{~m}$ shows very low and low resistivities at the western half of the area corresponding to clay, Nile silt and Nile mud, the eastern half of the area is occupying by high and very high resistivities for sand and sandstone. The slices at depth 8.2 and $11.1 \mathrm{~m}$ exhibit very low resistivities corresponding to Nile silt and Nile mud at the western part of the area, the eastern part is occupying by sand and sandstone of high resistivities.

\subsection{Deep geoelectrical investigation tools}

The deep geoelectrical tool is represented by measuring 41 vertical electrical soundings (VES) of $\mathrm{AB} / 2$ ranging from $5 \mathrm{~m}$ to $500 \mathrm{~m}$ using the Schlumberger configuration (Fig.3). The data were acquired using a SYSCAL-R2 resistivity meter.

\subsubsection{D resistivity inversion}

The objective of the inversion process is to obtain a distribution of the electrical resistivity (model) whose response approaches the field data (apparent resistivity values) within the limits of data errors and that correlates well with all available data, especially the geological information (Santos and Sultan, 2008). The smoothness-constrained least-squares method has been widely used in 2-D and 3-D inversions of magnetotelluric, electromagnetic and geoelectrical data sets (DeGroot-Hedlin and Constable, 1990; Sasaki 1989, 1994 and 2001). The scheme adopted in this study is based on Sasaki $(1994,2001)$. The dc resistivity inverse problem can be expressed as

$$
\mathrm{J} \Delta \mathrm{p}=\Delta \mathrm{d}
$$

where $\Delta \mathrm{p}$ is the vector containing the corrections to the model parameters $\mathbf{p}, \Delta \mathbf{d}=\mathbf{y}^{\mathrm{c}-} \mathbf{y}^{\mathrm{ob}}$ is the vector of the differences between the model responses and the measured data, and $\mathrm{J}$ is the derivative matrix (Jacobian) containing the derivatives of the model responses. In the present study forty-one were inverted by using a new approach, the full description for this approach was presented in Santos and Sultan, 2008. The results of the 3D inversion firstly represented by Figure 6 which shows the comparison between measured and calculated apparent resistivity curves. The misfit between data and model responses is a good fitting for most VES stations with rms error less than $10 \%$ except the VES stations no.20, 39, 40 and 41 exhibit bad fitting. 


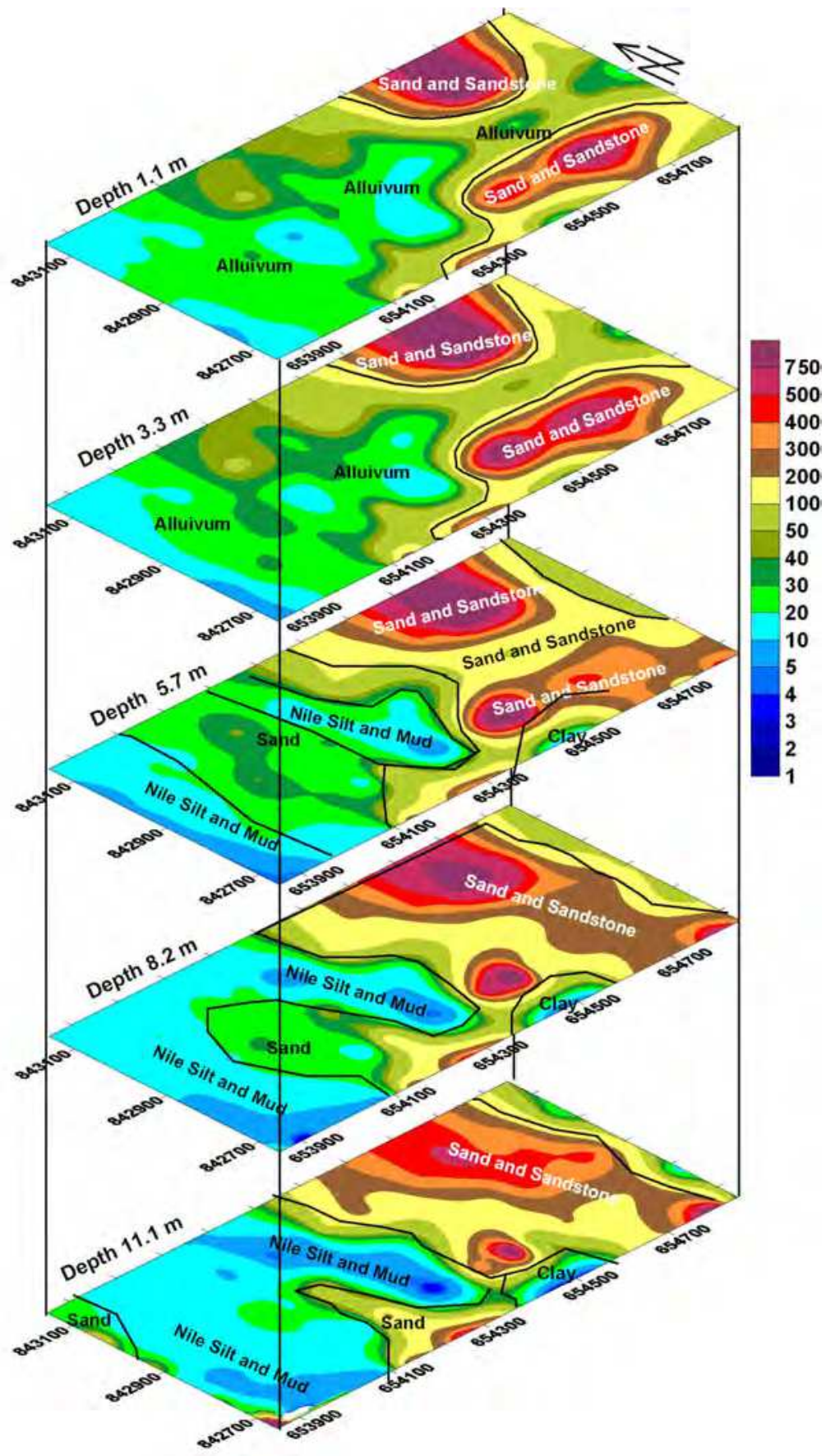

Fig. 5. 3D representation for dipole-dipole data 


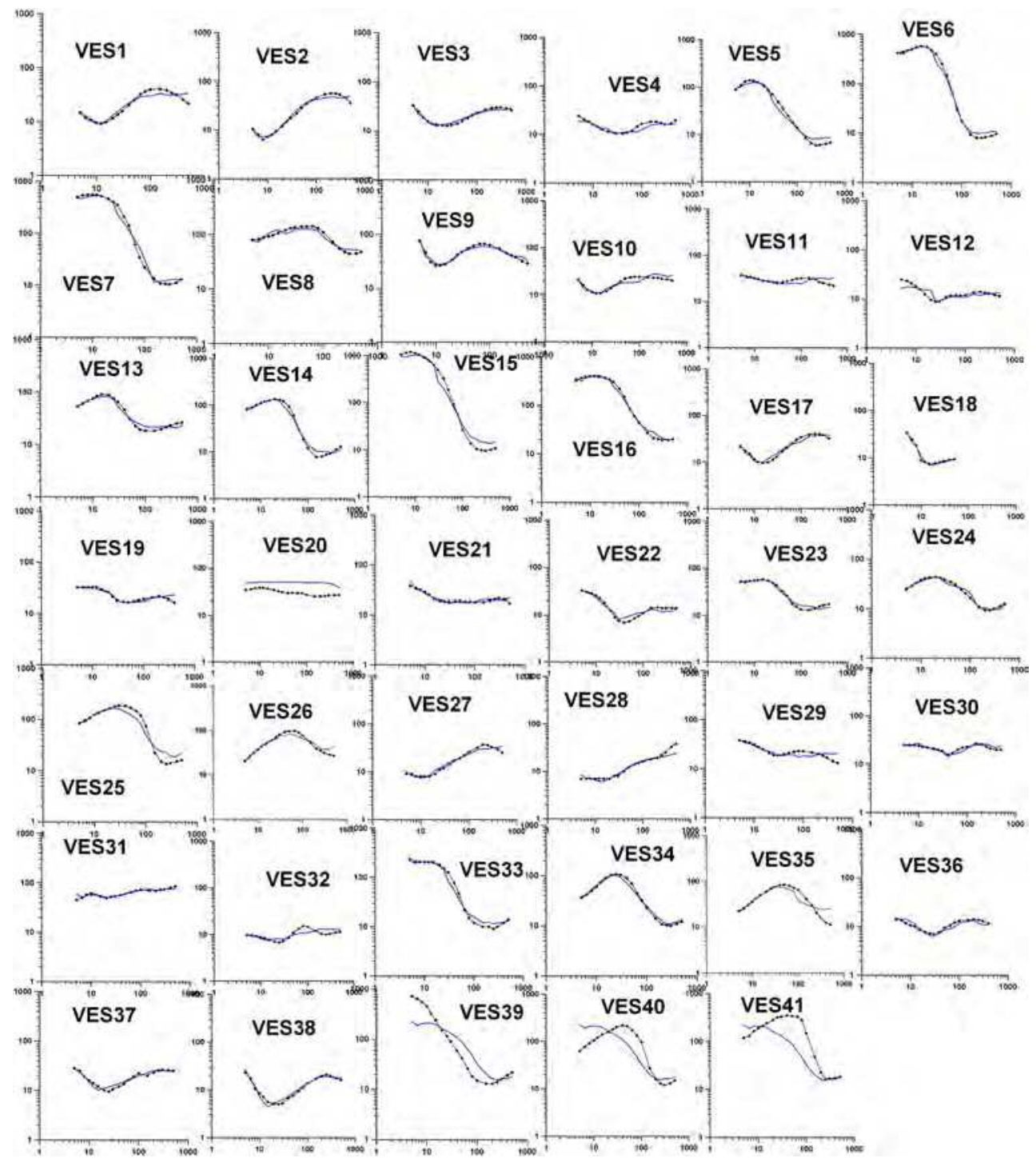

Fig. 6. Fitting of 3D VES inversion. 


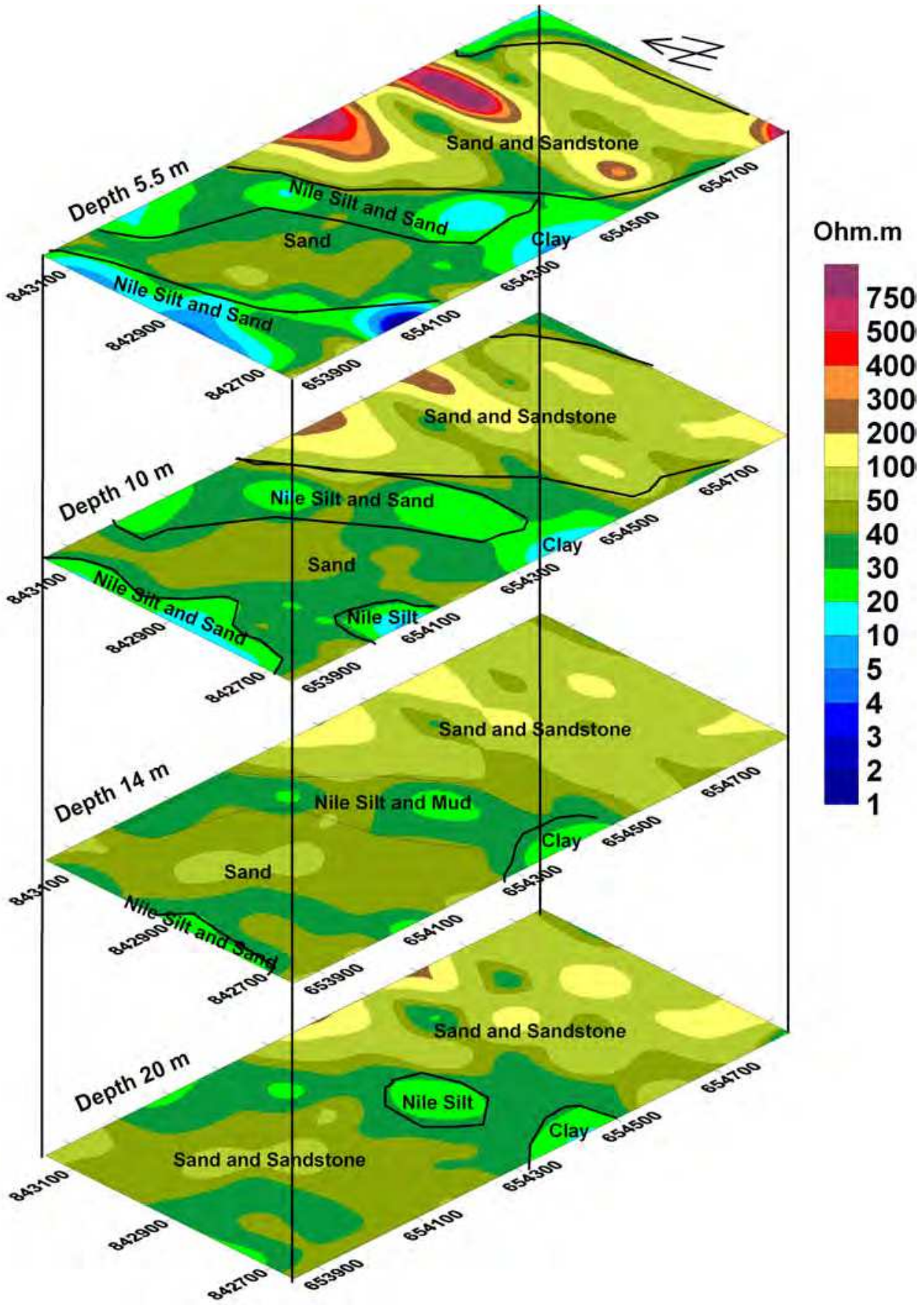

Fig. 7. 3D VES inversion slices at depth 5.5, 10, 14 and $20 \mathrm{~m}$. 


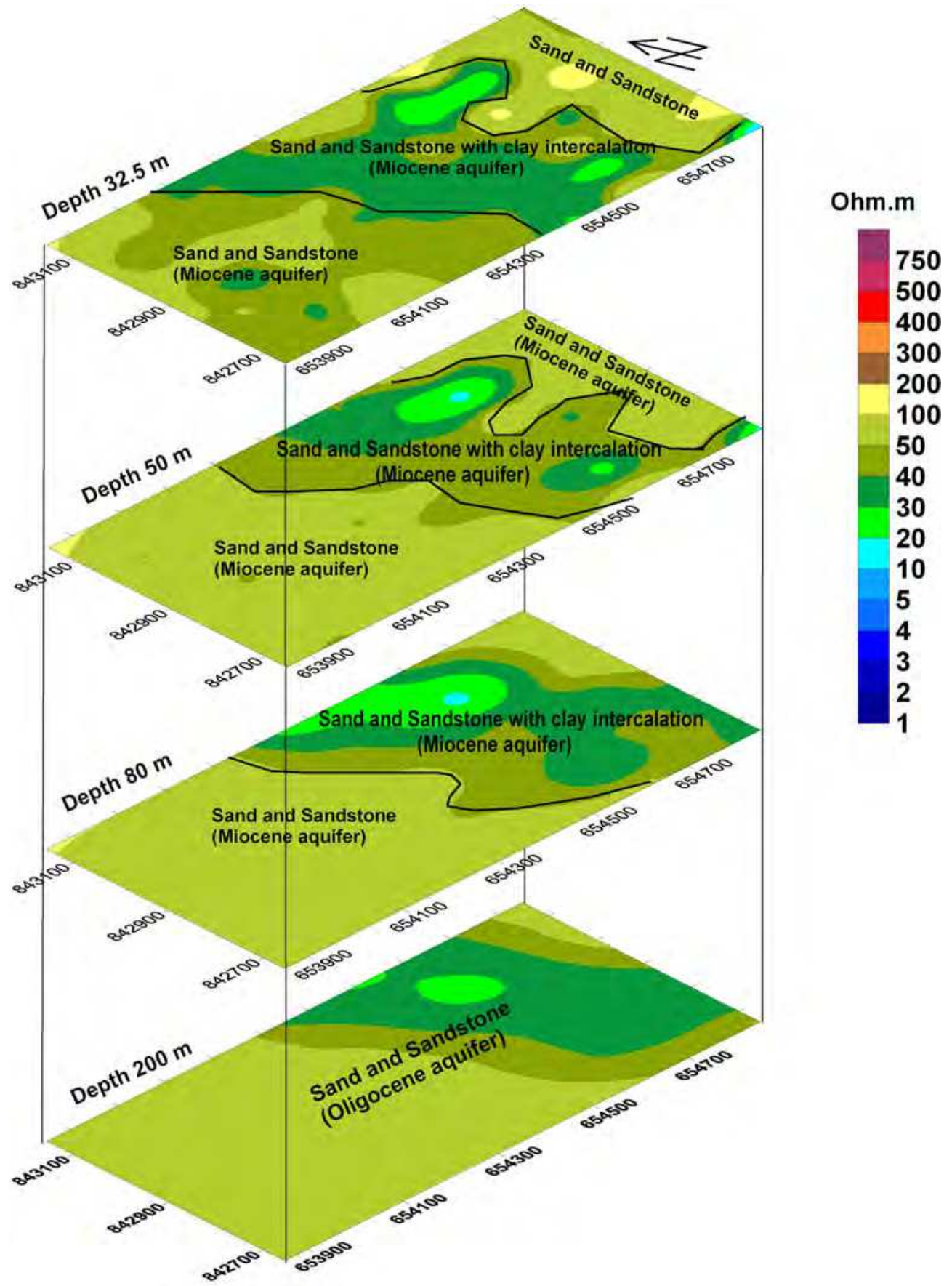

Fig. 8. 3D VES inversion slices at depth 32.5, 50, 80 and $200 \mathrm{~m}$. 


\subsubsection{D resistivity (VES) inversion slices}

The resistivity depth slices for the results of 3D inversion for VES data indicate that the study area show large variation in resistivities according to lithologic composition. 3D slice at depth $5.5 \mathrm{~m}$ exhibits very low resistivities ranging from $4-20 \mathrm{ohm} . \mathrm{m}$ according to Nile silt and Nile mud at the western and central part of the area, the low resistivities ranging from 30-50 ohm.m occupying the eastern part corresponding to sand. The eastern part of the area reveals high and very high resistivities ranging from $100-750 \mathrm{ohm} . \mathrm{m}$ for sand and sandstone. The depth slice at $10 \mathrm{~m}$ exhibits low resistivities corresponding to sand, Nile silt and Nile mud at the western part of the area, the eastern part reflects high resistivities according to sand and sandstone. The depth slices at 14 and $20 \mathrm{~m}$ show variation in resistivities ranging from 20-200 ohm.m corresponding to sand, Nile silt, Nile Mud and sandstone. The Miocene groundwater aquifer appears at depth slice 32.5 at the most study area where the Miocene aquifer consists of sand and sandstone of clay intercalation at the central part and the western part, the aquifer composed of sand and sandstone of moderately resistivities. The eastern part represents the dry Miocene sand and sandstone of high resistivities ranging from 50-100 ohm.m. The slices at depths 50 and $80 \mathrm{~m}$ represent the Miocene aquifer which cover all the area and composed of clayey sand and sandstone at the central part but the eastern and western part occupying by sand and sandstone. The basaltic sheet is not represented in 3D VES slices where the depths of basalt ranging between 80 and $120 \mathrm{~m}$ and 3D slices were represented by slices at depths 5.5, 10, 14, 20, 32.5, 50, 80 and $200 \mathrm{~m}$ (Figs.7 and 8).

\subsection{Hydrogeology of the study area}

Hydrogeology is the branch of geology that deals with the occurrence, distribution, and effect of groundwater. Some hydrogeologcal studies were carried out on the study area such as flow measurements to get an idea of water flow along the Ismailia Canal course and quantity of water which seeps into the groundwater from the canal, the measurements were carried by Geological Survey of Egypt (EGSMA, 1998) along section of length $28 \mathrm{~km}$ between Abu Zabal south study area (upstream) to Belbies north study area (down-stream). The results of the measurement indicated that the velocity of water in Canal is $0.87 \mathrm{~m} / \mathrm{s}$, a section area $=51.5 \mathrm{~m}^{2}$, amount of seepage $=45 \mathrm{~m}^{3} / \mathrm{s}$ for the upstream and an section area $=$ $90 \mathrm{~m}^{2}$, a velocity $=0.45 \mathrm{~m} / \mathrm{s}$, amount of seepage $=40.5 \mathrm{~m}^{3} / \mathrm{s}$ for the down stream. The measurements indicated also, the side flow input $=0 \mathrm{~m}^{3} / \mathrm{s}$ and output side flow $=4.13 \mathrm{~m}^{3} / \mathrm{s}$. The measurements include also 10 tests for estimating the hydraulic conductivity, the results of tests indicated the hydraulic conductivity is $0.102,0.265,1.233,1.427,0.081,0.061,0.0815$, $1.019,0.112$ and $0.122 \mathrm{~cm} / \mathrm{min}$. Water table was estimated through seven boreholes no. 1, 3, $5,7,9,11$ and 15 as shown in table (1).

The topographic map (Fig.9a) of the study area was constructed using elevation measurements which were carried out by using a Leica TC805 "Total Station" instrument of high resolution and good readability under all light conditions, where the study area is characterized by gentle slop from east $(57 \mathrm{~m})$ to west $(35 \mathrm{~m})$. Water table map (Fig.9b) shows two gentle gradients, the first from east to west and the second located at the southeast part of the area where the water table varied from 13.2 to $14.1 \mathrm{~m}$. The water table map indicates that the recharge source is Ismailia canal from southeast part and Miocene aquifer at the eastern part. Figure $9 \mathrm{c}$ reflects the depth of water ranging from 21 at the northwest part to 49 $\mathrm{m}$ at the northeast part. 

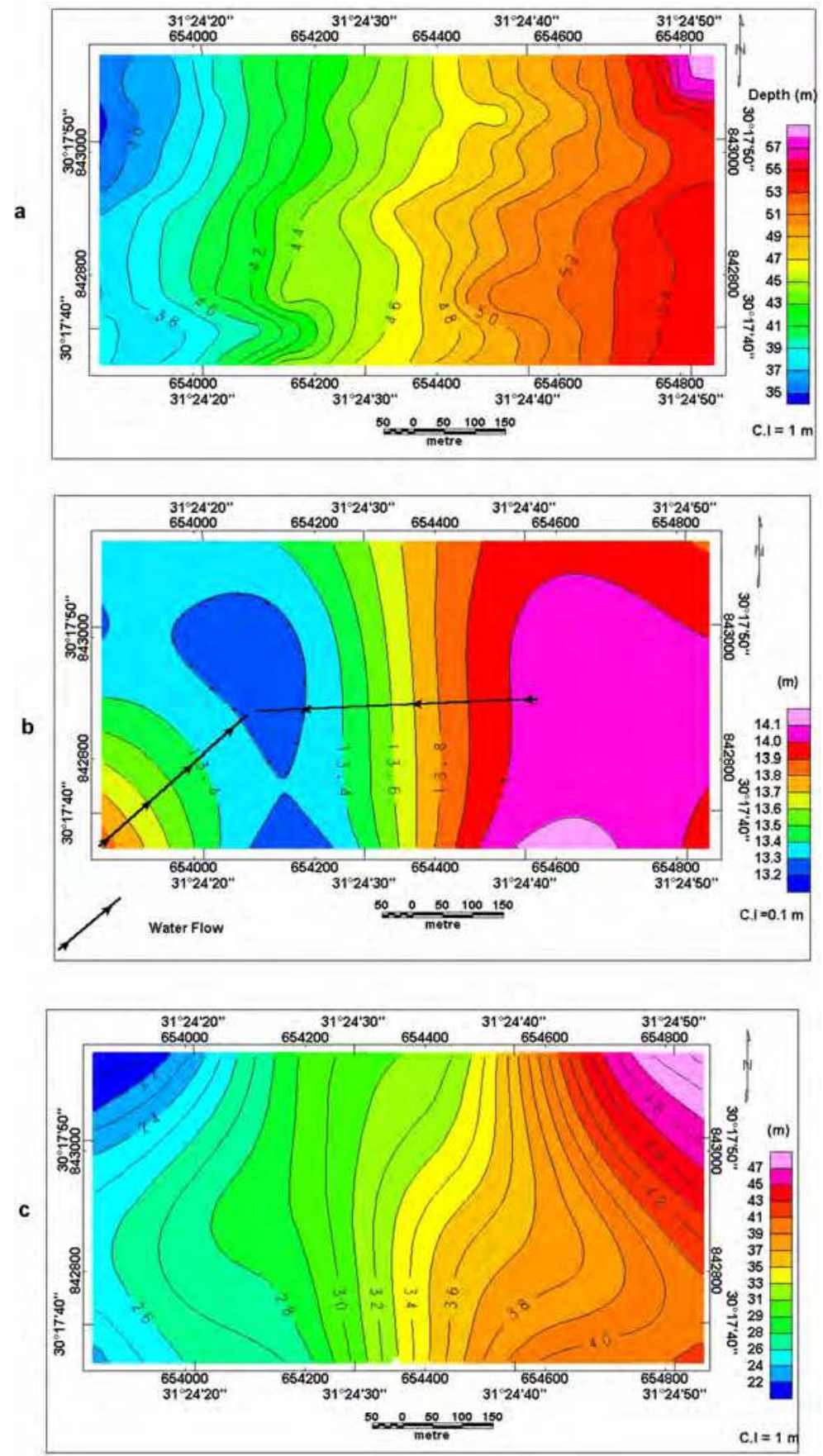

Fig. 9. a. Topographic map, b. Water table map and c. Water depth map 


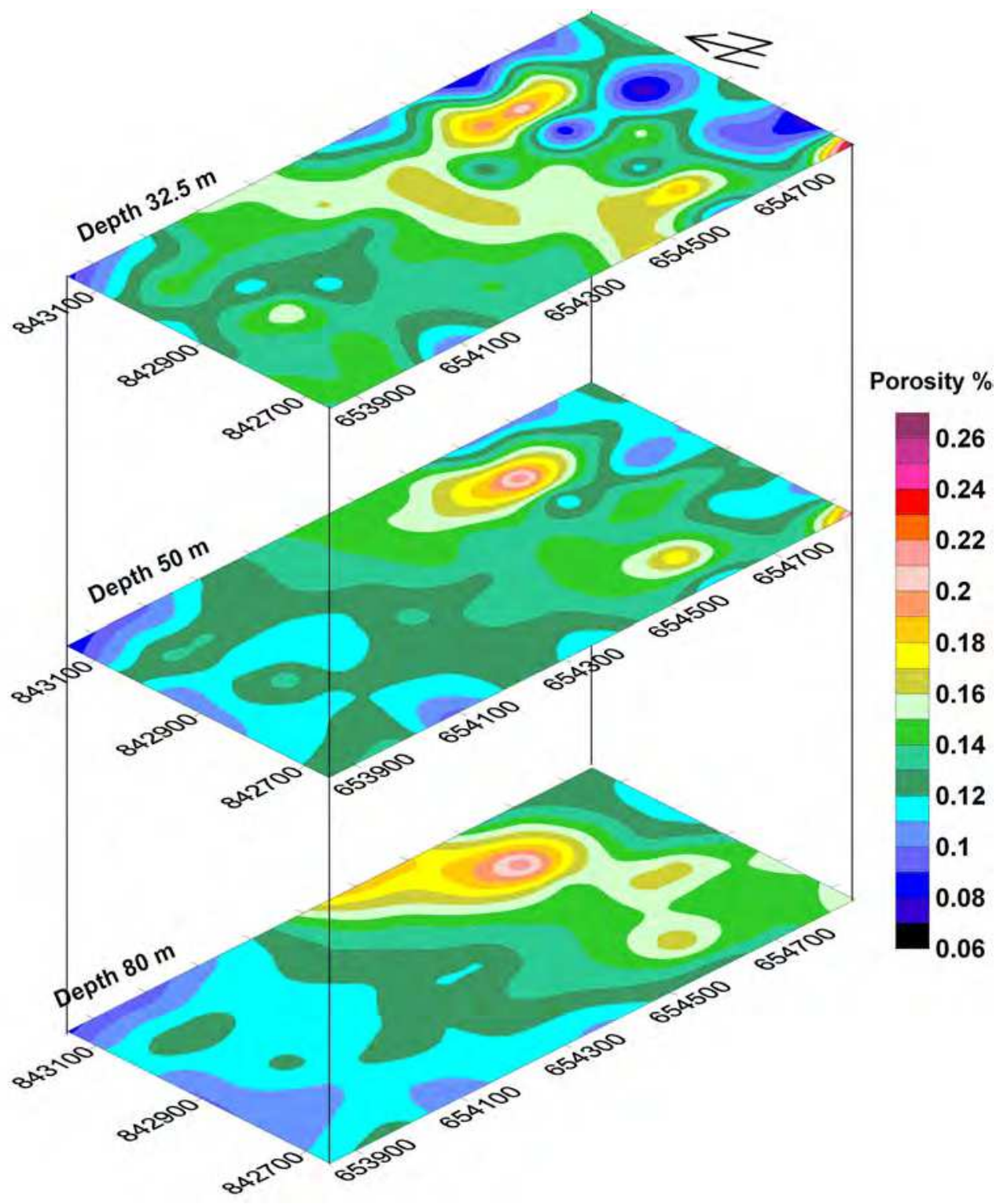

Fig. 10. Porosity percentage of the Miocene aquifer at depths $32.5,50$ and $80 \mathrm{~m}$. 


\subsubsection{Porosity estimation}

The porosity of the aquifer for clay free can be estimated through the equation 2 (Mark and Uri, 2004)

$$
\rho_{\mathrm{w}}=\rho_{\mathrm{b}} \phi^{2}
$$

Where the $\boldsymbol{\rho}_{\mathrm{b}}$ is the bulk resistivity of the rock, $\boldsymbol{\rho}_{\mathrm{w}}$ is the resistivity of water within the pore space, $\boldsymbol{\phi}$ is fractional porosity of the rock (approximately representing the volume of water filling the pore space), but the study area contains clay according to the boreholes results (Fig.2), Sen et al, 1988 summarized an equation for estimating the porosity through the bulk conductivity and groundwater conductivity for the aquifer contains clay (clayey sand and clayey sandstone), parameters in this equation are shown in equation 3

$$
\sigma=\phi^{m}\left\{\sigma_{w}+A Q_{v} /\left(1+C Q_{v} / \sigma_{w}\right)\right\}
$$

Where $\sigma$ is the conductivity of the aquifer, $\sigma_{w}$ is water conductivity, $\phi \boldsymbol{p}$ is porosity of the aquifer, $m, A$ and $C$ are constants $Q_{v}$ the clay charge contribution per unit pore volume. Sen et al determined these parameters through 140 core samples as the following $m=2, A=$ $1.93 \times m(\mathrm{mho} / \mathrm{m})(1 / \mathrm{mol}), Q_{v}=2.04$ and $C Q_{v}=0.7(\mathrm{mho} / \mathrm{m}) . \sigma_{w}$ was estimated through boreholes which drilled in the study area, the average values of $\sigma_{w}$ is $0.119 \mathrm{~s} / \mathrm{m}$, the results of porosity estimation of the Miocene aquifer were represented by Figure 10. The slice at depth $32.5 \mathrm{~m}$ (Fig.10a) reveals low porosity percentage at the eastern part ranging from 0.08 to $0.11 \%$, but the central part shows high porosity percentage ranging from 12 to $23 \%$. The porosity distribution at depth $50 \mathrm{~m}$ (Fig.10b) exhibits low porosity percentage at the eastern and western parts, the central part reveals high porosity $23 \%$. The porosity percentage at depth $80 \mathrm{~m}$ indicates that the most study area has high porosity percentage (13-23\%).

\subsubsection{Hydrochemistry of the area}

The hydrochemistry of the water has been described through six samples of water were taken from the boreholes and listed in table (1). The total dissolved salts (TDS) were represent by salinity map (Fig.11a) which indicates that the central part is occupying by high salinity $(2200 \mathrm{mg} / \mathrm{l})$ and the southwestern part reveals low salinity about $550 \mathrm{mg} / \mathrm{l}$.

\section{Water type}

The type of water is detected through the representation of boreholes data through Piper trilinear diagram and ratios of main ions in water chemistry through Schoeller diagram, where theses diagrams indicate that the water type is Na-Cl-SO4 for boreholes 3, 7 and 9; $\mathrm{Na}-\mathrm{HCO} 3-\mathrm{SO} 4$ for boreholes 11 and 15; Na-Cl-HCO3-SO4 for borehole 1 (Fig11b). The ratios of ions are higher for the borehole 9 and the lower ratios of ions are for Borehole 11 (Fig.11c). The total hardness have been estimated through the following equation (Reinhard, 2006)

$$
\text { Hardness }\left(\mathrm{H}_{\mathrm{tot}}\right)=0.14^{*} \mathrm{Ca}^{+2}+0.23^{*} \mathrm{Mg}^{+2}
$$

The results of hardness estimation has been tabulated in table (1), the result indicate that the total hardness of water is a slightly hard (17.1-60), but the borehole 9 exhibits $108.5 \mathrm{mg} / \mathrm{l}$ (moderately hard). 
Groundwater Management by Using Hydro-Geophysical

a

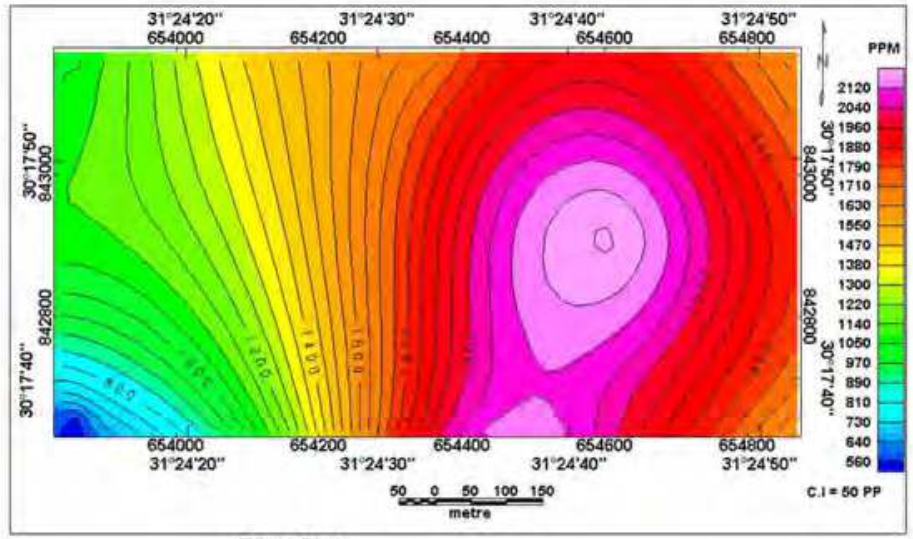

Piper Plot

b

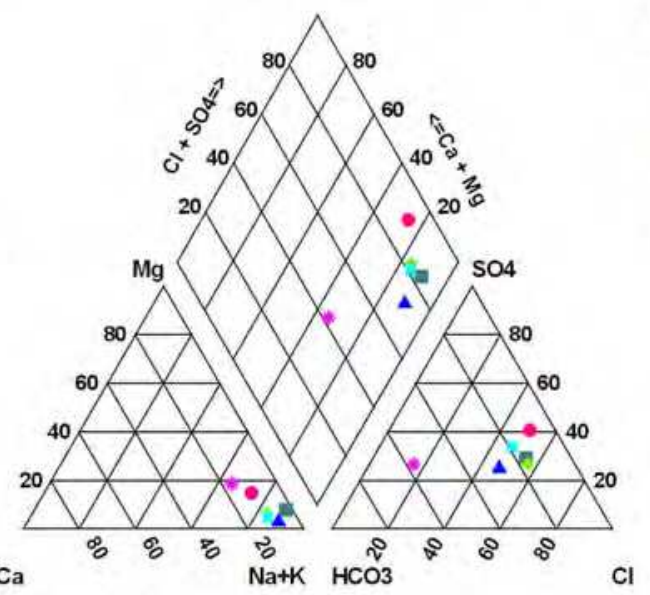

$$
\begin{aligned}
& \text { Legend } \\
& \text { * Bore1 } \\
& \text { * Bore11 } \\
& \text { Bore15 } \\
& \text { * Bore3 } \\
& \text { Bore7 } \\
& \text { - Bore9 }
\end{aligned}
$$

Schoeller Plot

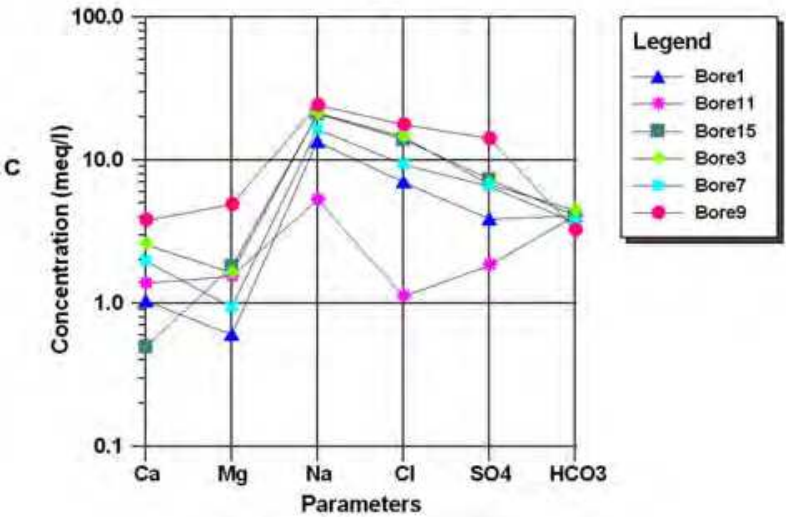

Fig. 11. a. Salinity map, b. Pieper Diagram and c. Schoeller diagram 


\begin{tabular}{|c|c|c|c|c|c|c|}
\hline & Borhole1 & Borhole3 & Borhole7 & Borhole9 & Borhole11 & Borhole15 \\
\hline $\begin{array}{l}\mathrm{Cl}^{-} \\
\mathrm{mg} / \mathrm{L}\end{array}$ & 261 & 516.4 & 329.1 & 624.2 & 39.7 & 493 \\
\hline $\begin{array}{l}\mathrm{SO}_{4}{ }^{-} \\
\mathrm{mg} / \mathrm{L}\end{array}$ & 184.8 & 326 & 314.1 & 677.3 & 88.6 & 350.3 \\
\hline $\begin{array}{l}\mathrm{HCO}_{3} \\
\mathrm{mg} / \mathrm{L}\end{array}$ & 247.1 & 271.5 & 222.7 & 198.3 & 247.1 & 247.4 \\
\hline $\begin{array}{l}\mathrm{Na}^{+} \\
\mathrm{mg} / \mathrm{L}\end{array}$ & 307.9 & 488 & 375.2 & 553.2 & 121.4 & 482.2 \\
\hline $\begin{array}{l}\mathrm{K}^{+} \\
\mathrm{mg} / \mathrm{L}\end{array}$ & 9.1 & 13.8 & 8.9 & 15.7 & 7.8 & 9.9 \\
\hline $\begin{array}{l}\mathrm{Ca}^{++} \\
\mathrm{mg} / \mathrm{L}\end{array}$ & 20.7 & 51.7 & 39.6 & 75.8 & 27.6 & 44.8 \\
\hline $\begin{array}{l}\mathrm{Mg}^{++} \\
\mathrm{mg} / \mathrm{L}\end{array}$ & 7.3 & 19.8 & 11.4 & 59.3 & 18.7 & 21.8 \\
\hline $\begin{array}{l}\text { TDS } \\
\mathrm{mg} / \mathrm{L}\end{array}$ & 1037.9 & 1687.2 & 1301 & 2213.8 & 550.9 & 1650.1 \\
\hline $\begin{array}{l}\mathrm{TH} \\
\mathrm{mg} / \mathrm{L}\end{array}$ & 330.5 & 348 & 290.3 & 593.5 & 351.2 & 314 \\
\hline $\begin{array}{l}\mathrm{PH} \\
\mathrm{mg} / \mathrm{L}\end{array}$ & 7.61 & 7.77 & 7.86 & 7.85 & 7.86 & 7.54 \\
\hline $\begin{array}{l}\text { EC } \\
\mu \mathrm{mho} / \mathrm{cm}\end{array}$ & 850 & 1250 & 1000 & 3250 & 700 & 1300 \\
\hline $\begin{array}{l}\text { Total } \\
\text { Hardness } \\
(\mathrm{mg} / \mathrm{l})\end{array}$ & 27.551 & 50.194 & 46.596 & 108.461 & 16.705 & 54.056 \\
\hline $\begin{array}{l}\text { Water table } \\
\text { (m) }\end{array}$ & 13.58 & 13.8 & 13.28 & 14.05 & 13.84 & 14.3 \\
\hline $\begin{array}{l}\text { Total depth } \\
\text { (m) }\end{array}$ & 50 & 50 & 75 & 128 & 50 & 50 \\
\hline $\begin{array}{l}\text { Elevation } \\
(\mathrm{m})\end{array}$ & 34 & 44.8 & 42 & 51.5 & 37.5 & 55.6 \\
\hline
\end{tabular}

Table 1. Hydrochemistry data collected from drilled boreholes in the study area.

\section{Conclusion}

Through the interpretation of the geophysical and hydrogeologicat data we can concluded that the shallow part of the stratigraphic section of the study area consists of Nile silt, Nile mud and clay while the eastern part exhibits high resistivities corresponding to sand and sandstone for this reason the eastern part of the study area is suitable for constructions The depth of the Miocene aquifer is ranging from 32.5 to $80 \mathrm{~m}$, the quality of the water is good and suitable for drinking and agricultural purposes where the salinity ranging from 550$2200 \mathrm{gm} / 1$ and the total hardness is ranging between 16.7-108.5 gm/1. The depth of the basaltic sheet ranging from 75 to $250 \mathrm{~m}$. The area dissected by fault elements of NW-SE, NESW and N-S trend. 


\section{References}

DeGroot-Hedlin C. and Constable S.C., 1990. Occam's inversion to generate smooth, twodimensional models from magnetotelluric data. Geophysics, 55, 1613-1624

Edwards, L.S., 1977. A modified pseudosection for resistivity and induced polarization. Geophysics, 42, 1020-1036.

Geological Survey of Egypt (EGSMA), 1998. Geology of Inshas Area, Geol.Surv. of Egypy, internal report

Geosoftw Program (Oasis Montaj), 1998. Geosoft mapping and application system, Inc, Suit 500, Richmond St. West Toronto , ON Canada N5SIV6

Keller, G.V., and Frischknecht, F.C., 1996: Electrical methods in geophysical prospecting, Pergamon Press.

Li, Y., and Oldenburg, D. W., 1992, Approximate inverse mappings in DC resistivity problems: Geo hys. J. Int., 109, 343-362.

Loke, M. H., and Barker, R. D., 1996a, Practical techniques for 3D resistivity surveys and data inversiton: Geophysical Prospecting, 44, 499-523.

Loke, M. H., and Barker, R. D., 1996b, Rapid least-squares inversion of apparent resistivity pseudo-sections using quasi-Newton method: Geophysical Prospecting, 44, 131152

Laurence Bentley and Mehran Gharibi, 2004 : Case study, Two- and three-dimensional electrical resistivity imaging at a heterogeneous remediation site, Geophysics, Vol. 69, No. 3, P. 674-680,

Mark Goldman and Uri Kafri; 2004 : Hydrogeophysical Applications in Coastal Aquifers, Applied Hydrogeophysics, NATO Science Series, published by IOS Press, Amsterdam.

Monteiro Santos F.A and Sultan S.A.; 2008: On the 3-D inversion of Vertical Electrical Soundings: application to the South Ismailia - Cairo Desert Road area, Cairo, Egypt, Journal of Applied Geophysics, 65, pp 97-110

Reinhard Kirsch; 2004 : Groundwater Geophysics, A Tool for Hydrogeology, text book, ISBN 10 3-540-29383-3 Springer Berlin Heidelberg New York.

Rijo, L., 1984, Inversion of three-dimensional resistivity and induced-polarization data: 54th Ann. Internat. Mtg., Soc. Expl. Geophys., Expanded Abstracts, 113-117

Sasaki Y., 1989. Two-dimensional joint inversion of magnetotelluric and dipole-dipole resistivity data. Geophysics, 54, 254-262.

Sasaki Y., 1994. 3-D resistivity inversion using the finite element method. Geophysics, 59, 12, 1839-1848.

Sasaki Y., 2001. Full 3-D inversion of electromagnetic data on PC. Journal of Applied Geophysics, 46, 45-54.

Sen, P.N., Goode, P.A. and Sibbit, A., 1988. Electrical conduction in clay bearing sandstones at low and high salinities. J. Appl. Physics, 63 (10), 4832-4840

Sultan, S.A., Monteiro Santos F.A (2008) : 1-D and 3-D Resistivity Inversions for Geotechnical Investigation, J. Geophys. Eng. 5, pp 1-11

Sultan S.A, Santos F.A.M, and . Helaly A.S; 2011: Integrated geophysical analysis for the area located at the Eastern part of Ismailia Canal, Egypt, first online, Arabian geosciences journal, 4, 735-753

Telford, W.M., Geldart, L.P., and Sheriff, R.E., 1990: Applied Geophysics (2nd Edition), Cambridge University Press. 
Thompson, D.T.T., 1982. Euler, a new technique for making computer assisted depth estimates from magnetic data, Geophs.V.47.pp.31-37.

Ward, S., 1990 : Resistivity and induced polarization methods, in Ward, S., Geotechnical and environmental geophysics, Vol.1: SEG Investigation in geophysics 6, 147-189 


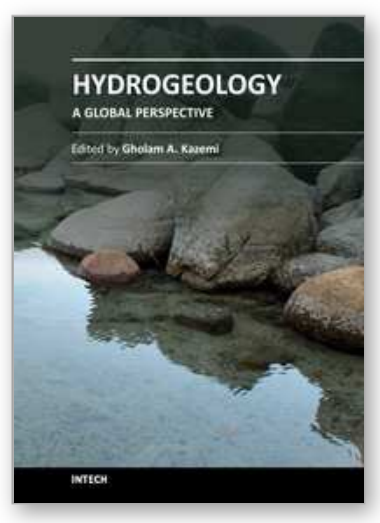

\author{
Hydrogeology - A Global Perspective
}

Edited by Dr. Gholam A. Kazemi

ISBN 978-953-51-0048-5

Hard cover, 222 pages

Publisher InTech

Published online 10, February, 2012

Published in print edition February, 2012

The field of groundwater hydrology and the discipline of hydrogeology have attracted a lot of attention during the past few decades. This is mainly because of the increasing need for high quality water, especially groundwater. This book, written by 15 scientists from 6 countries, clearly demonstrates the extensive range of issues that are dealt with in the field of hydrogeology. Karst hydrogeology and deposition processes, hydrogeochemistry, soil hydraulic properties as a factor affecting groundwater recharge processes, relevant conceptual models, and geophysical exploration for groundwater are all discussed in this book, giving the reader a global perspective on what hydrogeologists and co-scientists are currently working on to better manage groundwater resources. Graduate students, as well as practitioners, will find this book a useful resource and valuable guide.

\title{
How to reference
}

In order to correctly reference this scholarly work, feel free to copy and paste the following:

Sultan Awad Sultan Araffa (2012). Groundwater Management by Using Hydro-Geophysical Investigation: Case Study: An Area Located at North Abu Zabal City, Hydrogeology - A Global Perspective, Dr. Gholam A. Kazemi (Ed.), ISBN: 978-953-51-0048-5, InTech, Available from: http://www.intechopen.com/books/hydrogeology-aglobal-perspective/groundwater-management-by-using-hydro-geophysical-investigation-case-study-an-arealocated-at-north-

\section{INTECH}

open science | open minds

\section{InTech Europe}

University Campus STeP Ri

Slavka Krautzeka 83/A

51000 Rijeka, Croatia

Phone: +385 (51) 770447

Fax: +385 (51) 686166

www.intechopen.com

\section{InTech China}

Unit 405, Office Block, Hotel Equatorial Shanghai

No.65, Yan An Road (West), Shanghai, 200040, China

中国上海市延安西路65号上海国际贵都大饭店办公楼 405 单元

Phone: +86-21-62489820

Fax: $+86-21-62489821$ 
(C) 2012 The Author(s). Licensee IntechOpen. This is an open access article distributed under the terms of the Creative Commons Attribution 3.0 License, which permits unrestricted use, distribution, and reproduction in any medium, provided the original work is properly cited. 